\title{
FREQUENCY OF OCCURRENCE OF ORGANISATIONAL MANAGEMENT DYSFUNCTION: FROM THE PERSPECTIVE OF YOUNG PEOPLE ENTERING THE LABOUR MARKET
}

\begin{abstract}
The article deals with issues directly related to organizational irregularities. Its aim is to investigate the degree of exposure of young people to organizational dysfunctions, as there is now a clear research gap regarding the scale of the problem in this group of employees. The article presents successively why young workers are particularly exposed to this type of phenomena. The essence and causes of the problem are shown. An attempt was made to systematize organizational dysfunctions. The most important threats resulting from irregularities are also presented. In addition, on the basis of quantitative research, an attempt was made to determine the scale of the problem among people with short work experience and the effects of these organizational dysfunctions in this social group were examined. A full understanding of the mechanisms involved in the occurrence of organizational irregularities is very important from a social point of view as it can help to reduce the scale of the problem.
\end{abstract}

Keywords: organisational pathology, organisational dysfunctions, young workers.

\section{INTRODUCTION}

Capital is an indispensable element of the functioning of any organisation. It allows the realisation of a company's strategy and the production of added value. It is also a decisive factor in competitive advantage. Until recently, cost optimisation that enables to generate savings was considered the most frequently used to build the company's position in the market. Over the years, however, it turned out that global market shock has changed the perception of strategic planning, risk and business (PARP, 2015). More and more attention is paid to human capital as one of the most important values. Competent and experienced employees characterised by energy, persistence and resourcefulness (King, 2005) can be the best ones for crisis situations and unforeseen events.

There are often numerous irregularities in human resource management. These behaviors are called organisational dysfunctions. By definition, one of the meanings of dysfunction is incorrect phenomena and processes in social life, but this term can also be applied to business relationships (Kamińska, 2014). In this case, it concerns all phenomena that are inconsistent with statutory law, generally accepted social and ethical principles.

\footnotetext{
${ }^{1}$ Magdalena Inglot, MSc, Department of Projects Management and Security Policy, Faculty of Management, Rzeszow University of Technology, 10 Powstańców Warszawy Ave., 35-959 Rzeszow; e-mail: m.inglot@prz.edu.pl. ORCID: 0000-0001-5859-1366.
} 
This type of behavior is fostered by the development of civilization, which contributes to exerting pressure on the efficiency of action, the alienation of the individual in society or the extension of working time. Seemingly, these phenomena in the initial stage may be beneficial for enterprises, but over time, they have a destructive impact on employees and, consequently, on organisations. In the literature on the subject, there are many publications dealing with the problem of organizational dysfunctions, but there is a clear research gap regarding the scale of this problem affecting young workers. Young people, who start their careers, are particularly vulnerable to the effects of dysfunctional behaviour. They are often characterized by enthusiasm and commitment, but they do not have enough experience. When they ecounter organisational pathologies, they are often unable to cope with such problems. This leads to negative effects in their further professional careers, but it may also impact on their private life. That is why it is so important to fully understand the mechanisms associated with the occurrence of organisational irregularities. This can significantly reduce the scale of the problem.

The aim of the article is to show the influence of organisational irregularities on the functioning of enterprise culture with particular emphasis on the determinants of occurrence and the effects they may cause. Moreover, it is necessary to examine to what extent young people are exposed to organisational dysfunctions.

\section{THE DETERMINANTS OF ORGANISATIONAL PATHOLOGIES}

Dysfunctions can disrupt the proper functioning of the enterprise and adversely affect its social system. They can take place over a long proid of time, which in turn leads to waste in a moral or (and) economic sense (Pasieczny, Glinka, 2016), exceeding the limits of social tolerance and resulting in the reduction of effectiveness (Choroszczak, 2015).

Pathologies in social groups most often come from problems and disorders in interpersonal relationships. When interpreting the sources of this type of behavior, it is appropriate to carry out comprehensive analysis of the knowledge provided by various fields: psychology, sociology, anthropology, medicine or organisational behavior (Van Fleet, Griffin, 2006). An unequivocal classification of the causes of organisational dysfunctions is not easy, because the abuses usually occur when several factors appear simultaneously and are dependent on the specificity of enterprises. Most often, however, the common element turns out to be the lack of compliance with the principles of cooperation, such as trust, responsibility and proper communication (Lewicka, 2011).

The organisations that do not create a space for discussion, considering problems or accepting the possibility of making mistakes, exert a strong emphasis on their employees (Wells, 2006). In connection with the above, there may be abuse in organisations occurs between managers and subordinates. This phenomenon is most common in centralized organisations where the management has a strong influence on the organisational climate, strategy and structure (Kets De Vries, Miller, 1984).

There are many mistakes made by employers, such as relying too much on procedures, disregarding proven solutions in the pursuit of new products, shifting responsibility for any mistakes and a lack of willingness to obtain knowledge from employees. On the other hand, firmness and rationalization in decisions made by managers may be perceived as ruthlessness and unfairness (Pasieczny, 2012). Such an opinion is not always justified due to the lack of full information among employees. That is why it is so important to present and properly justify decisions. 
Paradoxically, the law turns out to be another element contributing to the emergence of organisational dysfunctions. Defective legal regulations and improperly functioning state institutions are assessed as one of the basic barriers to ethical management (Szczupaczyński, 2011). Following only the regulations may turn out to be insufficient, as there are often inconsistencies or ambiguous provisions. That is why it is so important to strengthen them with ethical codes (Singh, Prasad, 2017).

Moreover, the source of organisational pathologies, which are synonymous with organizational dysfunctions, may be the actions undertaken in response to the crisis. The crisis is associated with strong competition and a struggle for a position on the market. The situation often requires ruthless and aggressive behaviour. The company, to a large extent, focuses on the implementation of tasks that are to contribute in the first place to the survival on the market. Such an approach helps in achieving market stabilization, but it is not necessarily accompanied by social and humanistic success (Miklaszewski, 2013). Unethical behaviour becomes a means to achieve goals. An integrated and trustworthy team characterized by honesty and trust often transforms into a group focused only on the tasks set. It is worth noting, however, that the situation may often be the opposite and that pathological organisations may cause the various types of crises, including even the industrial ones (Miller, 1988).

It often turns out that employees who have experienced organisational pathologies later commit abuses in the work environment by themselves (Lewicka, 2011). Certain dysfunctions determine subsequent dysfunctions. Employees justify the committed abuses by unethical behavior of their co-workers. The internal consent and the lack of adequate regulations and ethical standards make difficult to prevent and detect disfunctions in enterprises. A thorough understanding of the cause of the problem helps to determine the reason, this type of situation arose and to deduce why young people are participants in the abnormalities.

\section{THE CLASSIFICATION OF IRREGULARITIES IN ENTERPRISES}

It is not easy to clearly classify abuses and dysfunctions in enterprises. Deviations can take many forms, vary in intensity, and may also depend on the type of enterprise. Moreover, the procedure of the occurrence of irregularities is usually not repetitive. Irregularities can often penetrate one another then their division will also be blurred. However, the adoption of a certain system enables researchers to arrange distant problems and issues (Szostek, 2015). The most common and comprehensive classification is considered to be the typology proposed by S. L. Robinson and R. J. Bennet (1995). This classification will allow for the identification of organizational pathologies with the strongest impact in order to examine the scale of the related problem. These dysfunctions require a quick and decisive response.The groups of dysfunctions were distinguished, differing in terms of the strength of their impact on the environment and their influence on the organisation or other employees:

1. Production irregularities:

a. Taking excessive breaks,

b. Leaving early,

c. Intentionally working slow,

d. Wasting resources. 
2. Property dysfunctions:
a. Accepting kicbacks,
b. Sabotaging equipment,
c. Stealing from company,
d. Lying about hours worked.

3. Political irregularities:
a. Showing favouritism,
b. Blaming co-workers,
c. Gossiping about co-workers,
d. Competing non-beneficially.

4. Personal aggression:
a. Verbal abuse,
b. Sexual harassment,
c. stealing from co-workers,
d. Endangering co-workers.

Production dysfunctions are characterized by relatively low harmfulness and they are classified as moderate deviations. Their common feature is always waste. Employees perform their duties incorrectly, which hinders to achieve the company's goals and strategy. The examples of such behavior include devoting working time to private affairs, insufficient attention to tasks, being late and misusing company assets (Slowak, Regenfelder, 2016). The abuses of this type often result in the irregularities of greater harmfulness (Szostek, 2016) and require the need to conceal the inconvenient facts.

Property dysfunctions are significantly harmful to the company. This group includes sabotage, corruption, economic theft or the use of stimulants in the workplace. The sabotage is an international and destructive influence on an organisation's performance (Ambrose, Seabringht, Schminke, 2002). Its causes may be related to the desire to take control, a manifestation of thoughtlessness or an act of helplessness when other forms of protest did not bring the desired results (Bugdol, 2007). The sabotage can manifest itself through a destruction of the work environment, a passive attitude or a lack of commitment. The theft applies to both tangible goods and intellectual property (Payne, Gainey, 2004). As for enterprises, it is often associated with the risk of stealing items related to key competences. The corruption is each time meeting the expectations of third parties using positions and people receiving an undue advantage in return (Bartosz, 2019). Unfortunately, in practice, it is often tolerated despite verbal condemnations (Graycar, 2015). This phenomenon disrupts the functioning of market mechanisms, disturbs economic development, and endangres the image of the organisation. The use of stimulants in the workplace is also a problem for many organisations. This happens despite bans and sanctions (Olak, Bonusiak, 2012). These types of pathologies reduce the concentration of employees, physiological disorders or are often the causes of accidents.

Political irregularities include low-harm interpersonal acts. They may concern gossip, favouritism, protection, surveillance and reporting. The surveillance is the exercise of supervision over an employee without his consent (Ibrahim, 2016). An initiator may be the employer, but also other associates. In the latter situation, the phenomenon turns into reporting. However, this activity is not always the same as informing. Gossips play a significant role in the social and economic system. They can affect both business situations and interpersonal relationships. The gossip can become a form of aggression and turn into a conflict (Bugdol, 2007). Favouring and patronage are elements of the abuse of power. 
They are related to better treatment of stakeholders due to private considerations. Nepotism is even an narrower phenomenon because it only affects family members (Rosicki, 2012). All these processes are harmful because they do not build a culture of trust.

The last area in the typology of organisational dysfunctions is personal aggression. It may cause a very strong threat to interpersonal relationships. This group of pathologies includes sexual harassment or mobbing. The first one is a form of discrimination. This phenomenon includes unacceptable sexual behavior, such as unwanted sexual comments, gestures or sexual activities (Quick, MsFadyen, 2016). In this way, aggressors create an intimidating, hostile and offensive work environment that threatens the employees' sense of security (Burn, 2019). Another threat with equally serious consequences is mobbing. It is concerned with deliberate mental abuse that affects social relations, communication, the current work and life situation. It manifests itself in prolonged and unfounded harassment, terror and psychological violence (Kowal, Pilarek, 2011). The purpose of this procedure is to humiliate, intimidate and limit the ability of defense. The phenomenon is based on manipulation and leads to the social isolation of a victin, self-depreciation, powerlessness and separation from co-workers (Duffy, Sperry, 2007). These irregularities not only have negative consequences for the individual and the entire organisation, but also violate human dignity.

\section{THE CONSEQUENCES OF ORGANISATIONAL DYSFUNCTIONS}

One of the most common consequences of organisational irregularities is chronic stress of the employee (Kessler, McGonagle, 1990). The fear caused by negative stimulus contributes to psychological destabilization. The consequences of these actions affect the mental and physical spheres of a person. In practical terms, stress is associated with exhaustion, tension, and the feeling of being unable to solve a difficult situation (Leśniewska, 2015). At the time of its occurrence, physiological and biochemical changes take place. Stress is an inseparable element of life, but it is more isible in professioal work. It is a desirable phenomenon because it promotes the generation of motivation and has a stimulating function, but after exceeding the limit of the optimal level of stress, the effectiveness drops significantly (Quillian-Wolver, Wolwer, 2011). This happens very often among employees who are affected by organisational abuse, particulary in cases of unhealthy competition, reporting, surveillance or mobbing, i.e. interpersonally targeted irregularities.

The people most susceptible to stress are the ambitious employees with high expectations, a great sense of mission, a strong commitment, for whom the inability to achieve the set goals causes a significant dissonance (Bańkowska, 2016). These employees are characterized by negating their own load limit. It is especially often noticeable among the people starting their professional careers. The difficult situation related to the occurrence of organisational dysfunctions, combined with these features, can clearly affect the mental health of employees. It was found that $10 \%$ of mental disorders are associated with occupational diseases (Leśniewska, 2015). This phenomenon is particularly noticeable in Japan, where due to professional problems, approximately 2,100 people took their own lives in 2016 (Kalińska, 2017). It is 8.94\% of all suicides (Pacholczyk, 2020). This shows the scale and reality of the problem.

Chronic stress can turn into professional burnout. It is associated with long-term involvement in emotionally burdensome matters and manifests itself in physical, mental 
and emotional exhaustion (Maslach, Schaufeli, Leiter, 2001). The phenomenon of occupational burnout is dynamic. It consists of the five stages (Kraczla, 2013). The first phase is connected with physiological complaints. Then there is a social disturbance related to the problems in interpersonal relationships. The third phase is associated with intellectual disorders such as the difficulties appear in information processing and logical thinking. The next stage concerns the behavioral changes associated with the decline of responsibility. The last phase is loss of faith in the values one believe in. Then one feels an inner void. Professional problems and irregularities disrupt the employee's private life and are associated with emotional exhaustion. Another suggestion to classify the symptoms of burnout is loss of commitment, irritation towards colleagues, lack of concentration, use of stimulants and a feeling of "emptiness" (Maslach, 2011). The burdens resulting from this phenomenon are also transferred beyond the organisational boundaries (Acar, Aupperle, 1984).

In these cases, the companies have to cope with the reduced productivity and more absenteeism due to illness. It is also characteristic to increase the probability of making mistakes and problems with timeliness. In extreme cases, it may even lead to strikes. If an employee decides to resign, then the company bears the costs of the severance pay, the recruitment and the training of a new employee (Ostrowska, Michcik, 2014). Indirectly, by examining the frequency of these effects, conclusions can be drawn about the frequency of irregularities. Such stimulation will also be carried out in the study. All these effects can be counteracted by eliminating irregularities in the organisation.

\section{THE SCALE OF THE PROBLEM OF ORGANISATIONAL PATHOLOGIES IN RELATION TO THE PEOPLE ENTERING THE LABOUR MARKET - THE RESEARCH RESULTS}

The research was conducted in order to better understand the scale of the occurrence of organisational irregularities affecting people starting their careers. It was made by using the CAWI method based on gathering information through interviews in electronic form, applied in conducting quantitative research (Nowak, 2007). The selected technique allows for a reliable measurement, and the study results can be generalized. The survey covered issues related to dysfunctions at the organizational and interpersonal levels. According to the classification, those characterized by high harmfulness were selected. The influence of dysfunction on the occurrence of chronic stress or occupational burnout was examined. The survey questions had a closed structure. They were directed to internet groups associating employees. It was noted that people taking part in the study should not work for more than 2 years. The study was conducted at the $95 \%$ confidence level, and the maximum error of this analysis is $6.79 \% .223$ people took part in the survey. The study group included 152 women (68.16\%) and 71 men (31.84\%). All responses were received in April 2020.

The study finds that for $78.9 \%$ of those people the attachment to work was conditioned by the necessity to obtain funds for daily living. Over $40 \%$ of respondents declared that they did their job only because they were not able to find a better offer. Only $37 \%$ of people were satisfied with the atmosphere in their workplace. Over $32.7 \%$ of respondents claimed that work gave them the opportunity for personal development. Moreover, $15 \%$ of people surveyed had concerns about the difficulties associated with changing jobs. Only $12.1 \%$ of respondents declared satisfaction from the received salary. As other benefits related to the performance of professional activities, the most frequently mentioned advantages were 
a benefit package, flexible working hours and a position corresponding to one's own interests. The results are shown in Figure 1.

It turned out that candidate favouritism during recruitment process is still a significant problem. Over $41.2 \%$ of respondents declared that the companies where they worked employed the family or friends of the management staff. Less than $20 \%$ of participants said that they have no knowledge of this dependency. The scale of the problem may be even greater.

In fact, $63.3 \%$ of respondents experienced the symptoms of workplace bullying, relate to the use of long-term and unfounded psychological violence. Most respondents declared that they received an excessive amount of work.

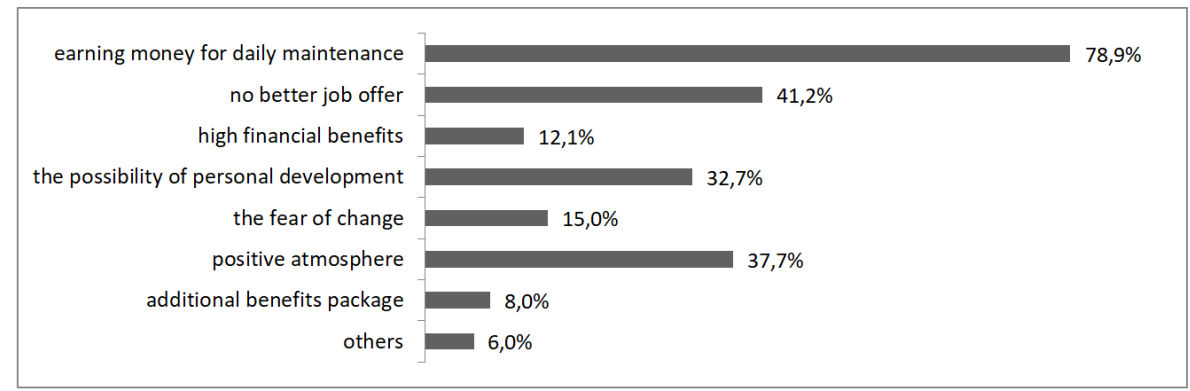

Figure 1. The determinants of performing work in the current position

Source: The author's own work based on the research results.

Another serious problem is unjustified criticism - over $32.7 \%$ of respondents encountered this phenomenon. About $18.1 \%$ of the people experienced wrong questioning of competences for a long time. Over $10 \%$ were insulted and socially isolated from other employees. Only $6 \%$ of people surveyed said that they experienced at least four symptoms of mobbing at the same time, which indicates a very serious problem. Most respondents who experienced these behaviors were forced to continue working because they earned a living. That is why it is particularly difficult to stop this circle of aggression.

Another significant problem is sexual harassment. Almost $50 \%$ of respondents experienced its manifestations. The most common problem concerns comments regarding appearance and clothing. About $36.2 \%$ of respondents met them in the workplace. Erotic jokes were experienced by $32.7 \%$ of respondents. Only $3 \%$ of young employees declared that they received sexual offers while performing their professional duties and this group included only women. Over $6 \%$ of the respondents experienced an attempt of physical contact, and also in this case, those people declared that their current job was necessary for them to obtain funds for daily living.

The performance of professional duties is often accompanied by stress. The phenomenon intensifies in particular when irregularities occur. Already $8 \%$ of people who started their professional activity, declared that they felt stressed at a very high level. This group mainly includes the people for whom their work provides the possibility of daily living. Most of respondents (38.2\%) were accompanied by moderate stress. Only $9 \%$ people surveyed described the level of stress in the performance of professional duties as very low. 
Chronic stress can be one of the causes of burnout in the workplace. Only $34 \%$ of those who started their careers said that they have never experienced any the symptom of professional burnout. About $40 \%$ of respondents felt irritation towards their colleagues. About $23.1 \%$ of people talked about the lack of commitment. The problems with concentration had $27.6 \%$ of respondents. Only $8 \%$ of people surveyed couldn't cope with a given situation and used stimulants to improve their well-being. About $26.6 \%$ of respondents admitted that they experienced the feeling of "emptiness". Only $4 \%$ of all respondents noticed at least the four symptoms, which might indicate an advanced stage of occupational burnout.

What is more, respondents stated that the role of management is very important in preventing organisational irregularities. Over $75 \%$ people surveyed assessed that the management with their actions, decisions and approach can significantly counteract the occurrence of this type of behavior. Only $13 \%$ of those people claimed that the role of managers in this area was small or not at all. It proves the enormous role of the management staff, as well as the responsibility for proper functioning and proper relations between employees.

\section{CONCLUSIONS}

People who have just started their professional careers are much exposed to organisational dysfunctions. This is due to the lack of professional experience and limited employment opportunities. Young people most often take up their professional activity due to the necessity to obtain funds for daily living. In this case, the position of the employer is much higher.

This contributes to the occurrence of chronic stress, which, according to the research, affects about $30 \%$ of the young workers, and to occupational burnout, which is also a significant problem in this social group. Over $60 \%$ of employees surveyed experience workplace bullying. Usually, people who present their situation as the most difficult in terms of the abuses are forced to do so by a complicated financial situation. Managers should be aware of the fact that employees affected by organisational irregularities are much less effective which negatively affects the functioning of the organisation.

Certainly, the issues discussed in the article still require the further development in the form of qualitative research, but the scale and reality of the problem and its negative effects for people just starting their professional activity are clearly signaled. The fight with days functions makes since for the empoloyees who can derive satusfaction from their work and the management staff who cares about the efficiency and image of a team, so it is worth paying a lot of attention and interest to this issue.

\section{REFERENCES}

Ambrose, M., Seabringht, M., Schminke, M. (2002). Sabotage in the workplace: The role of organizational injustice. "Organizational Behavior and Human Decision Processes", Vol. 89, No. 1.

Bańkowska, A. (2016). Syndrom wypalenia zawodowego - symptomy i czynniki ryzyka. „Pielegniarstwo Polskie”, No. 2.

Bugdol, M. (2007). Gry i zachowania nieetyczne w organizacji. Warszawa: Difin.

Burn, S. (2019). The Psychology of Sexual Harassment. “Teaching of Psychology”, Vol. 46, No. 1. 
Choroszczak, J. (2015). The Signs of Organizational Pathology in Companies Wholly Owned by the State Treasury - The Identification and the Analysis of the Causes of the Phenomenon Studied. "Business and Non-profit Organizations Facing Increased Competition and Growing Customers' Demands”, Vol. 14.

Duffy, M., Sperry, L. (2007). Workplace Mobbing: Individual and Family Health Consequences. "The Family Journal", Vol. 15, No. 4.

Graycar, A. (2015). Corruption: Classification and analysis. "Policy and Society”, Vol. 34, No. 2.

Ibrahim, S. W. (2016). A comprehensive review on intelligent surveillance systems. "Communications in Science and Technology", Vol. 1, No. 1.

Kalińka, A. (2017). Zapracować się na śmierć. Samobójstwa pracowników to nie tylko japoński problem. [Access: 01.12.2020]. Access on the internet: https://www.money.pl/gospodarka/ wiadomosci/artykul/mobbing-samobojstwa-pracownikow, 234,0,2228970.html

Kamińska, B. (2014). Mobbing jako patologia w kierowaniu personelem. „Zeszyty Naukowe Wyższej Szkoły Humanitas. Zarządzanie”, No. 1.

Kenneth, W. A., Aupperle, E. (1984). Bureaucracy as organizational pathology. "Systems Research", Vol. 1, No. 3,

Kessler, R. C., McGonagle, K. A. (1990). Chronic stress, acute stress, and depressive symptoms. “American Journal of Community Psychology”, Vol. 18, No. 5.

Kets de Vries, M. F. R., Miller, D. (1984). Neurotic Style and Organizational Pathology. "Strategic Management Journal", Vol. 5, No. 1.

King, J. B. (2005). The Top 10 Reasons Businesses Succeed. "EzineArticles”, No. 5.

Kowal, J., Pilarek, G. (2011). Mobbing jako problem etyki w zarządzaniu. „Annales. Etyka w życiu gospodarczym", Vol. 14, No. 1.

Kraczla, M. (2013). Wypalenie zawodowe jako efekt dtugotrwatego stresu, „Zeszyty Naukowe Wyższej Szkoty Humanitas. Zarządzanie”, No. 2.

Leśniewska, G. (2015). Stres a równowaga życiowa. „Studia i prace Wydziału Nauk Ekonomicznych i Zarzadzania”, Vol. 40, No. 2.

Lewicka, D. (2011). Dziatania nieetyczne i nadużycia w organizacji. Problematyka oszustw w świetle badań. „Zeszyty Naukowe Wyższej Szkoty Bankowej we Wrocławiu”, No. 24.

Maslach, C., Schaufeli, W. B., Leiter, M. (2001). Job Burnout. “Annual Review of Psychology”, No. 52.

Maslach, C. (2011). Wypalenie - w perspektywie wielowymiarowej [w:] Sęk, H., red., Wypalenie zawodowe. Przyczyny i zapobieganie. Warszawa: Wydawnictwo Naukowe PWN.

Miklaszewski, L. (2013). Zachowania nieetyczne $w$ warunkach zmiany kulturowej na przykładzie firmy inwestycyjnej. „Zeszyty Naukowe Wyższej Szkoły Bankowej we Wroctawiu”, No. 4.

Miller, D. (1988). Organizational Pathology and Industrial Crisis. "Industrial Crisis Quarterly", Vol. 2, No. 1.

Nowak, S. (2007). Metodologia badań społecznych. Warszawa: Wydawnictwo Naukowe PWN

Olak, A., Bonusiak, A. (2012). Zagrożenia $w$ funkcjonowaniu organizacji zwiazane z patologiami kadrowymi. „Acta Scientifica Academiae Ostroviensis. Sectio A, Nauki Humanistyczne, Społeczne i Techniczne”, No. 1.

Ostrowska, M., Michcik, A. (2014). Stres w pracy-objawy, konsekwencje, przeciwdziałanie. „Bezpieczeństwo Pracy: Nauka i Praktyka”, No. 5. 
Pacholczyk, N. (2020). Japonia. W miesią więcej samobójstw, niż ofiar COVID-19 od początku epidemii [Access: 01.12.2020]. Access on the internet: https://wiadomosci.gazeta.pl/ wiadomosci/7,114881,26563082,japonia-w-miesiac-wiecej-samobojstw-niz-ofiar-covid19-od.html

PARP (2015). Kapitat ludzki jako wartość firmy. Narzędzie Pomiaru Kapitału Ludzkiego wdrożenie, analiza $i$ wnioski [Access: 27.11.2020]. Access on the internet: https://www. parp.gov.pl/storage/publications/pdf/parp\%208_\%20kapital\%20ludzki_mm.pdf

Pasieczny, J. (2012). Patologie organizacji w okresie kryzysu. „Zarzadzanie finansami”, No. 4.

Pasieczny, J., Glinka, B. (2016). Obszary dysfunkcji organizacyjnych. „Zeszyty Naukowe Politechniki Śląskiej", Vol. 93.

Payne, B., Gainey, R. R. (2004). Ancillary consequences of employee theft. "Journal of Criminal Justice”, Vol. 32, No. 1.

Quick, J. C., McFadyen, M. A. (2016). Sexual Harassment: Have We Made Any Progress? "Journal of Occupational Health Psychology", Vol. 22, No. 3.

Quillian-Wolever, R. E., Wolever, M. E. (2011). Stress Management at Work [In:] Quick J. C., Tetrick, L. E., ed., Occupational Health Psychology. Washington: American Psychological Association.

Robinson, S. L., Bennett, R. J. (1995). A Typology of Deviant Workplace Behaviors: A Multidimensional Scaling Study. "The Academy of Management Journal”, No. 2.

Rosicki, R. (2012). Rzecz o nepotyzmie i kumoterstwie. „Przegląd Politologiczny”, No. 2.

Singh, C., Prasad, M. (2017). Code of Ethics in an Organisation. "Intrnational Journal of Application or Innovation in Engineering \& Management”, Vol. 6, No. 5.

Slowak, A., Regenfelder, M. (2016). Creating value, not wasting resources: sustainable innovation strategies. "Innovation: The European Journal of Social Science Research", Vol. 30, No. 3.

Szczupaczyński, J. (2011). Makrospołeczne otoczenie przedsiębiorstwa jako źródto barier etycznego zarzadzania. „Przegląd Organizacji”, No. 9.

Szostek, D. (2015). Dysfunkcjonalne zachowania pracowników: zarys problematyki. „Zarzqdzanie Zasobami Ludzkimi”, No. 1.

- (2016). Wybrane przejawy patologii w miejscu pracy - doniesienie z badania wśród pracujących studentów WNEiZ UMK w Toruniu. „Zarządzanie Zasobami Ludzkimi”, No. 1.

Van Fleet, D. D., Griffin, W. (2006). Dysfunctional organization culture: The role of leadership in motivating dysfunctional work behaviors. "Journal of Managerial Psychology", Vol. 21, No. 8.

Wells, J. T. (2006). Nadużycia w firmach Vademecum zapobieganie i wykrywanie. Warszawa: LexisNexis.

DOI: 10.7862/rz.2021.hss.13

The text was submitted to the editorial office: December 2020.

The text was accepted for publication: June 2021. 